\title{
AHSG wt Allele
}

National Cancer Institute

\section{Source}

National Cancer Institute. AHSG wt Allele. NCI Thesaurus. Code C113822.

Human AHSG wild-type allele is located in the vicinity of $3 q 27$ and is approximately $8 \mathrm{~kb}$ in length. This allele, which encodes alpha-2-HS-glycoprotein, plays a role in the modulation of bone formation. 